\title{
The Influence of Organizational Communication Climate on Organizational Communication Satisfaction to Non-Profit Organization CIOFF Indonesia
}

\author{
De Rembulan Ayundhasurya ${ }^{1}$, Firman Kurniawan ${ }^{2}$, \\ ${ }^{1}$ Magister Communication Management Social and Political Studies, Universitas Indonesia, Jakarta, Indonesia \\ ${ }^{2}$ Magister Communication Management Social and Political Studies, Universitas Indonesia, Jakarta, Indonesia \\ de.rembulan@ui.ac.id (De Rembulan Ayundhasurya), firman.kurniawan09@ui.ac.id (Firman Kurniawan)
}

\begin{abstract}
CIOFF Indonesia is a non-profit organization of art and culture. This study aims to analyze the influence of organizational communication climate on organizational communication satisfaction in non-profit organization CIOFF Indonesia. This study uses qualitative research methods with observation through interview process. The literature review in this study is in the same area and using the same variable, which are organizational communication climate and organizational communication satisfaction. The result of this study indicates that organizational communication climate has an impact on organizational communication satisfaction in non-profit organization CIOFF Indonesia.
\end{abstract}

Keywords Organizational Communication Climate, Organizational Communication Satisfaction, Non-Profit Organization

\section{Introduction}

Organizations that want high productivity will depend on its members to achieve that desire. Members of an organization can interact with their co-workers, their subordinates, and their heads. When interacting, they exchange thoughts and experiences, and accept each other's attitudes and be- haviors. Good communication can result in a positive qual- ity of positive interpersonal relationships that will affect the quality of the organization.

A research conducted by Champbell (1970) shows that a good organizational climate is not only designed for the success of the organization, but also for the good of its members. The results of his research concluded that the more positive an organization's climate, the better the productivity. These results have a correlation with the views of Pace and Faules (2013) which states that a conducive, comfortable, and positive organizational climate is important to enhance work motivation of members within the organization.

Job satisfaction has a big effect to get optimal work result. When a person is satisfied with his/her job, that person will work hard by using all the ability to complete the job. Thus, job satisfaction is useful to maintain organizational productivity and improve work results. Job satisfaction is also one of the most important factors to attract and maintain qualified members. Dissatisfaction is the starting point of problems that arise within the organization, primarily because it creates a less-positive circumstances within the organization's work environment. When members of the organization feel dissatisfied with their work, their motivation and the quality of their works will be decreased as well.

An aspect arising as a result of work satisfaction is communication satisfaction (Muhammad, 2001: 88). Organizational communication satisfaction is the level of satisfaction that someone has by making perceptions of the communication environment that occurred (Redding in Pace and Faules, 2001). By those definitions, satisfaction depends on the 
perception of how each member views the organization's ability to achieve the expected goals through every existing communication process.

A positive relationship between organizational climate and job satisfaction can be explained through many studies. One of them can be seen from the results of research conducted by Litwin and Stringer (1968: 45-65) with the conclusion that the organizational climate has an impact on satisfaction and motivation, as well as on work productivity. According to Redding (in Pace and Faules, 2001: 148), the climate of an organization is more important than the skills or communication techniques to create an effective organi- zation. One of the basic assumptions of organizational cli- mate is that the perception and behavior of organization members will be influenced by the perception and behavior of other members of the organization. The organization's climate includes the flow of information and activities that involve communication process. Therefore, the result of the interaction done by organization members is expected to create a good organizational climate conditions.

As a non-profit organization, which is a national representative group in local art festivals, CIOFF Indonesia has the main objective of preserving Indonesian culture. A nonprofit organization represents an organization that has the ultimate goal of supporting an issue or thing by attracting public attention to a non-commercial purpose, regardless of monetary matters (Komang, 2008). CIOFF Indonesia establishes rules that become as reference and guidance for members to manage each member's duties and responsibilities so that the organization's main focus can be achieved. CIOFF Indonesia has an organizational structure that tends to be flat, so it has a tendency to centralize authority) on a certain party. It has a risk of dependency by giving it only on one person. In addition, the exchange of information that is only performed on small groups, especially the group of old members who have joined this organization longer than the others, leads to a lack of openness in spreading the in- formation to other members. This situation makes many members feel less worthy of other members at the same level of responsibility. Ineffective communication flows from the leader to those groups' members make delegation of tasks and responsibilities unclear, especially for those who were not included in that group. However, the leader is still demanding all the members to deal with any directions. CIOFF Indonesia needs to realize that good internal communication is a primary value for regulating the system and establishing a positive climate within the organization.

The research question of this research will be "is there any influence of organization communication climate to the organization communication satisfaction of the member of non-profit organization CIOFF Indonesia?". This study aims to know how organization climate influences the communication satisfaction at the member of non-profit organization CIOFF Indonesia.

\section{Literature and Methods}

\subsection{Organizational Communication Climate}

Communication has an important role in an organizational life. Communication within the organization is one of the main things that must be owned in order to achieve organizational goals. Organizational communication according to Wiryanto (2005) is defined as the activity of sending and receiving various messages of the organization within the formal or informal group of an organization.

Communication climate according to Denis in Arni (1995) is an objective quality of experience about the internal environment of the organization that includes the organization members' perception of messages and the relationship of messages with events that occur within the organization. An intimate communication climate will encourage its members to communicate openly, relaxed, and friendly with other members, and instead a negative communication climate makes the members cannot communicate openly and fraternally.

The organization's climate has several definitions. According to Tagiuri (1968), organizational climate is a relative quality of the internal environment of an organization experienced by its members, affecting their behavior and can be described as values of a set of certain characteristics of the environment.

Payne and Pugh (1976) argue that organizational climate is a concept that reflects the content and strength of the general values, norms, attitudes, behaviors, and feelings of members towards a social system.

In addition, Hillreiger and Slocum in Arni (1995) state that the organizational climate is a set of organizational attributes and subsystems that can be perceived by members of the organization, caused by the organization's system towards members and the environment.

The organizational communication climate according to Pace and Faules (2013) is a combination of perceptions of communication events, human behavior, members' responses to other members, expectations, interpersonal conflicts, and opportunities for the growth of the organization.

To analyze the communication climate within an organization, there are six factors according to Pace and Faules, which are:

1. Trust. Members at all levels of the organization should strive to develop and maintain trustworthy relationships, beliefs, and credibility supported by statements and actions.

2. Joint decision-making. Members at all levels of the organization should be invited to communicate and consult on all issues in all areas of the organization's policy, relevant to their position. Members of the organization should be given the opportunity to communicate and consult with the management above them in order to participate in the process 
of decision-making and goal setting.

3. Honesty. A general atmosphere of honesty and openness should be in all the relationships within the organization, and members are able to say what's on their minds regardless of whether they are speaking to peers, subordinates, or superiors.

4. Openness in downward communication. Downward communication shows the flow of messages from the boss or leader to the subordinates. Except for the purposes of classified information, members of the organization should be relatively easy to obtain information directly related to their current task. It affects their ability to coordinate their work and all things relate with the company, its organization, and plans.

5. Ability to listen in upward communication. Upward communication is a message that flows from the subordinate to the leader or from the lower level to the next level. Members at all levels of the organization should listen to suggestions from others or the report of problems raised by other members at the subordinate level within the organization on an ongoing and open-minded basis. Information from subordinates should be considered important enough to be implemented, unless there are contrary directions.

6. Attention to high-performance goals. Members at all levels of the organization should demonstrate a commitment to high-performance goals that result in high productivity, high quality, and low cost. It shows great concern to other members of the organization.

\subsection{Organizational Communication Satisfaction}

Satisfaction is a concept used to express the level of comfort (Pace and Faules, 2013). According to Downs and Hazen (1977), communication satisfaction is the satisfaction felt by individuals against various aspects of communication that exist within the organization. From this definition, communication satisfaction can be said as a condition when a sense of comfort with messages, media, and relationships that occur within the organization appear. Satisfaction shows how well the information can meet the requirements of the organization's members' demands of their demands on various information.

Terms of communication satisfaction refers to the satisfaction of a person to the relationship and the flow of information (Alsayed, Motaghi, and Osman, 2012). In general, satisfaction relates to the difference between what people want about their point of view of communication within an organization and what that person gets in relation to it. When members feel satisfied with the organizational communication flow, they will have a good relationships with others in the organization with a good flow of information. Therefore, their work can be done easily and should be better in result, and they can be solved all the problems using all the skills they have.

\subsection{Research Methods}

This research uses qualitative descriptive approach, with observation process, collecting of data based on fact in field, and interview. Qualitative descriptive approach is used to find out how the climate of organizational communication can improve communication satisfaction in CIOFF Indone- sia members.

The basis or reference of this research is the theories or findings through the results of various previous studies. One of the important supporting data for reference is prior research relevant to the questions in this study. Sources of data used in this study were taken from books, literature, and journals.

In this study, the selection of samples is using purposive sampling technique, which selectively chooses the information from respondents who have to master the problems that exist in this study. The use of purposive sampling technique is expected to give more effective result. This technique requires homogeneity as its way to gather respondents. The purpose of this study is to know the satisfaction on members who have the same experience in the organization and associated with communication climate. So, the homogeneity of its respondents is members who have the same experience, depend on how long they have been join this organization. Data collection methods used in this study are observation, interviews, and documentation. Interview is a technique of data collection by conducting question and answer directly to the respondent. Therefore, the respondents in this study are active members of CIOFF Indonesia.

The type of data used in this study is qualitative data as the source for information and explanation of the climate of organizational communication, and its influence to create organizational communication satisfaction. The results of the research using this method are expected to provide more indepth results, and supported by relevant data from re- search that has been done before.

\section{Result and Discussion}

Each organization should have a main goal to achieve, so that the organization must be able to have a strategy in achieving it. By understanding the goals of the organization, individuals and groups can know the behaviors and actions to be performed appropriately and in accordance with the planning. One strategy for organizations to experience significant development in the modern world is to manage data and human resources effectively.

Communication problems often occur in the process of organizing. Based on the results of observations and interviews conducted with respondents about the organization communications climate, obtained information that organizational communication that occurs in this organization is still experiencing obstacles, causing the climate of organizational communication becomes not really good. There is a 
high gap between members who have longer been in this organization and those who are newer. It makes the members of this organization less comfortable to talk with those who called 'seniors', as well as to provide criticism and suggestions. Ideas and complaints have not been fully accepted by superiors. This situation exists because the organizational structure is less effective, thus causing unequal workload.

Much information is only accepted by the upper layers of the steering committee, but the information has direct effect with the work of all members, whether incorporated in the steering committee or not. The problem is caused by the lack of open information in this organization. The climate of organizational communication in its context of openness can be seen through downward communication. Infrequent flow of information from superiors causes a bad communications climate perceived by the members. There is an expectation from superiors that all members should be aware of all information and fully accept the rules, but the existing information is not managed transparently. Belief in certain people and the number of members of the organization who are not in the same working time cause information is difficult to be accepted equal.

One goal of maintaining downward communication is to reduce suspicions arising from misinformation, as well as to prevent misunderstanding. These are often the case and experience from members of this organization. Therefore, many members of the organization of CIOFF Indonesia have not felt the satisfaction of communication in this organization yet.

\section{Conclusion}

From the results of this study, it can be concluded that the climate of organizational communication has an influence on the satisfaction of non-profit organization communication CIOFF Indonesia. Modern organizational management suggests that all organizational elements serve as a mutually dependent entity, explaining that the organization is not a closed system that is closely related to a stable environment, but an organization embracing an open system that can adapt to changes in its environment. In its management, modern organizations must be open, including in the information, so that the flow of information can be well and received equally by all members of the organization. This will have a positive impact on the communication satisfaction that the members will receive.

This research proposes some suggestions that can be implemented to improve the satisfaction of the non-profit organization of CIOFF Indonesia and other non-profit organizations, ie organizations which need to create a pleasant working climate for their members. The pleasant working climate is useful for creating more open communication among members. With open communication, members feel more comfortable to be in an organization so the organiza- tion will be able to increase the communication satisfaction of members in the organization. Increased communication satisfaction will have a positive impact on job satisfaction. Members of the organization will have great commitment and motivation so that the tasks and responsibilities of work will be completed properly. In addition, as academic advice in other studies that have the same field, it is better to use additional variables that are not present in this study, and to use more comprehensive research through quantitative or qualitative research directly with survey methods and in-depth interviews.

\section{REFERENCES}

[1] Ardana, K., Mujiati, N. W., and Sriathi, A. A. A., 2008, Perilaku Keorganisasian, Grahaa Ilmu, Yogyakarta.

[2] Campbell, J. P., 1970, Managerial Behavior, Performance, and Effectiveness, McGraw-Hill, New York.

[3] Dillard, J. P., Wigand, R. T., and Boster, F. J., "Communication climate and its role in organizations". European Journal of Communication, 2, 83-101. 1986.

[4] Downs, C. W., and Hazen, M. D., 1977, A Factor Analytic Study of Communication Satisfation. Journal of Business Commuication, 14(3), 63-74.

[5] Gibson, J. L., Ivancevich, J. M., Donelly, J. H. Jr, and Konopaske, R., "Organizational: Behavior, Structure, Processes”, Mc Graw-Hill, pp. 344-345. 2013.

[6] Goldhaber, G. M., 1993, Organizational Communication (Sixth Edition), McGraw-Hill, USA.

[7] Guzley, R. M., "Organizational Climate and Communication Climate - Predictors of Commitment to the Organization", SAGE Journals. Vol. 5, Issue 4, 1992.

[8] Litwin, G. H., and Stringer, R. A. Jr., 1968, Motivation and Organizational Climate, Harvard University Press, USA.

[9] Luthans, F., 2006, Perilaku Organisasi.Edisi ke-10, ANDI, Yogyakarta.

[10] McShane, S. L, and Mary, A. V. G., 2010, Organizational Behavior - Emerging Knowledge and Practice for the Real World 5th Edition, McGraw-Hill, USA.

[11] Muhammad, A., 1995, Komunikasi Organisasi, Bumi Aksara, Jakarta.

[12] Muhammad, A., 2001, Komunikasi Organisasi, Bumi Aksara, Jakarta.

[13] Muhammad, A., 2009, Komunikasi Organisasi, Bumi Aksara, Jakarta.

[14] Pace, R. W., and Faules, D. F., 2001, Komunikasi organisasi (terjemahan), Rosdakarya, Bandung.

[15] Pace, R. W., and Faules, D. F., 2013, Komunikasi Organisasi, Edisi ke-8 Diterjemahkan oleh: Mulyana, D., M. A., Ph.D, dkk, Remaja Rosdakarya, Bandung.

[16] Payne, R. W., and Pugh, E., 1976, Leadership and Practice Second Edition, Sage Publication, Inc., California.

[17] Robbins, SP., and Judge, 2011, Perilaku Organisasi, Salemba 
Empat, Jakarta.

[18] Sidiq, A., 2013, Pengaruh Iklim Komunikasi Organisasi dan Motivasi terhadap Kinerja Pegawai. (Survei pada Kantor Wilayah Pajak Yogyakarta). Universitas Islam Negeri Yogyakarta.

[19] Tagiuri, R., and Litwin, G. H., 1968, Organizational Climate: Explorations of a Concept. Harvard University (CAMBRIDGE, Mass.). Graduate School of Business Administration, USA.

[20] Wiryanto, 2005, Pengantar Ilmu Komunikasi, Gramedia Widiasrana Indonesia, Jakarta.

[21] Yantara, J. L., 2015, Analisis Faktor Kepuasan Komunikasi Organisasi di Apartemen Metropolis Surabaya. Jurnal e-Komunikasi Univ. Kristen Petra Surabaya. 